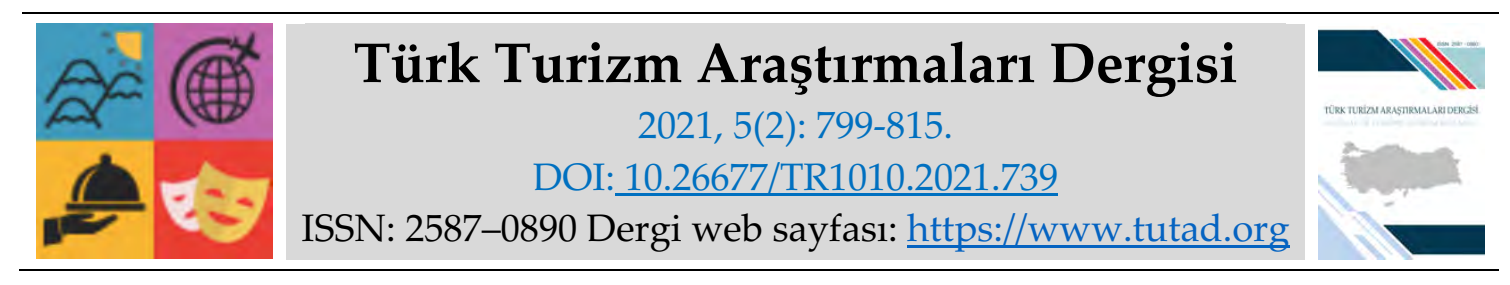

ARASTTIRMA MAKALESI

\title{
Nomadlıst'de Dijital Göçebeler Tarafından 2020'de En Fazla Tercih Edilen Destinasyonların Destinasyon Seçim Kriterlerine Göre Kümelendirilmesi
}

Dr. Öğr. Üyesi Serpil KOCAMAN, Alanya Alaaddin Keykubat Üniversitesi, Turizm Fakültesi, Antalya, e-posta: serpil.kocaman@alanya.edu.tr

ORCID: https://orcid.org/0000-0002-2037-7441

Öz

COVID-19 sürecinde dünyada uzaktan çalışma oranlarında ciddi artışlar yaşanmakta ve bu durum dünyada her geçen yıl daha popüler hale gelen dijital göçebelerin sayısını artırmaktadır. 2020 yılı içerisinde 1 milyondan fazla kişinin kullandığı nomadlist.com, dijital göçebelerin hem destinasyon seçimi hem iletişim ağıları için en fazla tercih ettiği platformların başında gelmektedir. Bu çalışmanın amacı Nomad List'de uluslararası veri tabalarından alınan güncel veriler ve 10 binden fazla üyenin değerlendirmeleri ile oluşan verileri analiz edip 2020 yılı içinde en çok tercih edilen ilk 20 destinasyona ait skorları kullanarak, destinasyonların nasıl kümelendiklerini tespit etmek ve küme ortalamalarına göre küme profillerini tanımlamaktır. İkincil veriler konunun pek çok kaynaktan alınmış özetini içerdiği için araştırmada NomadList üzerinden elde edilen ikincil veriler kullanılarak SPSS paket programı ile k-ortalamalar kümeleme analizi yapılmıştır. Kümeleme analizi sonucunda oluşan kümeler isimlendirilmiş ve ortalamalar açısından karşılaştırılmıştır. Analiz sonucunda yüksek toleransli-lüks dijital göçebe destinasyonları, düşük toleransl1-ekonomik dijital göçebe destinasyonları ve yüksek toleranslıekonomik dijital göçebe destinasyonları olarak üç küme elde edilmiştir.

Anahtar Kelimeler: Dijital Göçebe Turizmi, Dijital Göçebe Destinasyonu, Nomad List.

Makale Gönderme Tarihi: 09.02.2021

Makale Kabul Tarihi: 03.06.2021

\section{Önerilen Atıf:}

Kocaman, S. (2021). Nomadlıst'de Dijital Göçebeler Tarafından 2020'de En Fazla Tercih Edilen Destinasyonların Destinasyon Seçim Kriterlerine Göre Kümelendirilmesi, Türk Turizm Araştırmaları Dergisi, 5(2): 799-815.

(C) 2021 Türk Turizm Araştırmaları Dergisi. 


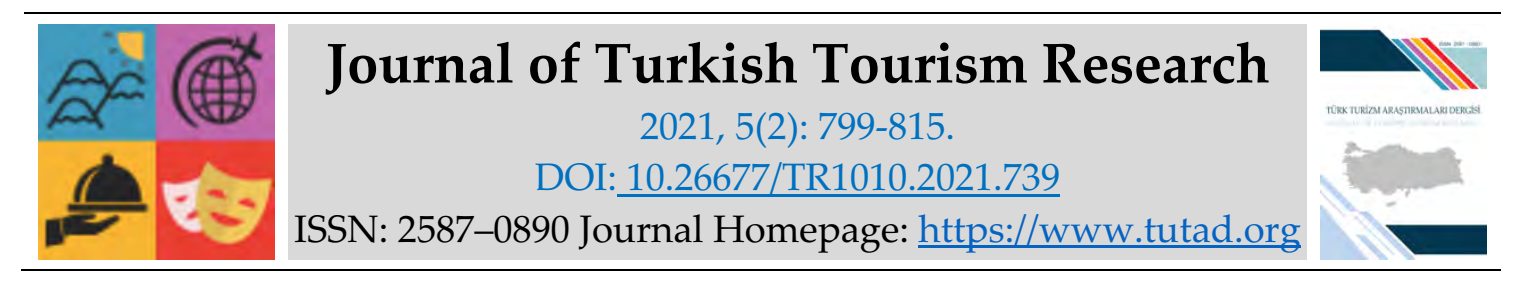

\title{
$\underline{\text { RESEARCH PAPER }}$
}

\section{Classification of the Most Preferred Destinations in 2020 By Digital Nomads in Nomad List According to Destination Selection Criteria}

Assistant Prof. Dr. Serpil KOCAMAN, Alanya Alaaddin Keykubat University, Faculty of Tourism, Antalya, e-mail: serpil.kocaman@alanya.edu.tr

ORCID: https://orcid.org/0000-0002-2037-7441

\begin{abstract}
In the COVID-19 process, there is a serious increase in the rate of remote working in the world, and this increases the number of digital nomads that are becoming more popular every year in the world. Used by more than 1 million people in 2020, nomadlist.com has become the most preferred platform for digital nomads for both destination selection and communication networks. The purpose of this study is to analyze the data in the Nomad List to determine how the top 20 most preferred digital nomad destinations are clustered in 2020 and to define cluster profiles according to cluster averages. K-means cluster analysis was used in the SPSS program for the data obtained through NomadList in the study. When the cluster analysis was analyzed and the means were compared. The analysis yielded three clusters as high-tolerance-luxury digital nomad destinations, low-tolerance-economic digital nomad destinations, and hightolerance-economic digital nomad destinations.
\end{abstract}

Keywords: Digital Nomad Tourism, Digital Nomad Destination, Nomad List.

Received: 09.02.2021

Accepted: 03.06.2021

\section{Suggested Citation:}

Kocaman, S. (2021). Classification of the Most Preferred Destinations in 2020 By Digital Nomads in Nomad List According to Destination Selection Criteria, Journal of Turkish Tourism Research, 5(2): 799-815.

(c) 2021 Türk Turizm Araştırmaları Dergisi. 


\section{Gíriş}

Dünya Turizm Barometresi'nin yeni sayısına göre, uluslararası turist girişlerinde yılın ilk yarısında \%65 oranında bir düşüş yaşanmıştır. Dünyadaki ülkeler sınırlarını kapattıkça ve pandemiye yanıt olarak seyahat kısıtlamaları getirdikçe, benzeri görülmemiş bir düşüş ile COVID 19'un turizm üzerindeki ciddi etkisini ortaya koymaktadır. UNWTO'ya göre, OcakHaziran 2020 döneminde uluslararası seyahat talebindeki büyük düşüş, 440 milyon uluslararası varış kaybına ve uluslararası turizmden elde edilen ihracat gelirlerinde yaklaşık 460 milyar ABD Doları tutarında bir kayıp anlamına gelmektedir. Şu an ki kayıp, 2009 yılında küresel ekonomik ve mali kriz sırasında uluslararası turizm gelirlerinde kaydedilen kaybın yaklaşık beş katını oluşturmaktadır (UNWTO, 2021).

Günümüz ekonomisinde, teknolojik gelişmeler sürekli ve neredeyse kaçınılmaz olarak kuruluşların iş modellerini, ürünleri ve hizmetleri veya pazarlama önlemlerini nasıl tasarladıklarını yeniden şekillendirir. Bununla birlikte, dijitalleşme yalnızca ekonomik aktiviteyi iş süreçleri açısından yenilemekle yetinmez, aynı zamanda bireysel olarak işin organizasyonundaki değişiklikleri de teşvik eder (Richter vd., 2018). Diğer bir ifade ile iş dünyasının dijitalleşmesi hem bireyleri hem de kuruluşları etkilemektedir. Sektörler genelinde teknolojik ve yapısal ilerleme, bireylere çalışmalarını zamandan ve mekândan bağımsız olarak yeniden düzenlemeleri için yeni bir potansiyel sunar (Nicholas ve Julian, 2021: 2111). Pandemi süreci bu değişimi hızlandırmış ve uzaktan çalışma sayılarındaki artış hızını kısa sürede beklenenin üstünde bir seviyeye taşımıştır.

Turizm için bilgi ve iletişim teknolojilerinin rolü, uzun zamandır popüler bir akademik araştırma konusudur. Ancak medya kaynakları, Bilgi İletişim Teknolojileri (BİT) etkilerinin turizm tedarik perspektifinin ötesine geçtiğini ve belki de seyahatin yaşamdaki potansiyel rolünü değiştirdiğini öne sürmektedir. Özellikle bu kapsamda, kendini "dijital göçebe" olarak tanımlayan bireylere atıfta bulunmaktadır (Reichenberger, 2017: 1). Dijital göçebe kavramı her ne kadar ilk olarak 1997 yılında kullanılsa da (Makimoto ve Manners, 1997), dijital göçebelerin turizm alanı açısından ele alınması çok yenidir (Putra ve Agirachman, 2016; Pecsek, 2018; Hall vd., 2019; Orel, 2019; Cook, 2020; Wiranatha vd., 2020; von Zumbusch ve Lalicic, 2020; Prabawa ve Pertiwi, 2020; Hermann ve Paris, 2020; Chevtaeva, 2021).

Dijital göçebeler, uzaktan çalışmalarına ve seyahat etmelerine imkân tanıyan, konumdan bağımsız, teknolojinin etkin olduğu bir yaşam tarzını benimseyen kişilerdir. Dünya çapında çok sayıda ortak çalışma alanı yaratan destinasyonlar, dijital göçebeleri cezbetmektedir (Chevtaeva, 2021). Estonya, Bermuda, Gürcistan, Barbados, Dubai, Hırvatistan ve Türkiye gibi birçok destinasyonun üst düzey yöneticileri tarafından yapılan açıklamalar dijital göçebe turizminin 2020 salgın krizinden sonra uzaktan çalışanlar için cazip bir vize politikası getirerek ekonomiyi yeniden başlatma potansiyelini öngörmektedir. Destinasyonlar dijital göçebe turizmi için gerek ortak çalışma alanları (co-working) gerekse destinasyondan beklentileri konusunda farkındalıklarını artırmak açısından bu konunun tartışılması önem taşımaktadır.

Dijitalleşmenin artmasıyla bağlantılı olarak iş ve boş zaman sınırlarının artan bulanıklığı, dijital göçebelere internete erişebildikleri her yerde çalışma özgürlüğü sunmaktadır (Richards, 2015: 343). COVID salgını turizm sektöründe büyük bir dalgalanma yaşanmasına yol açmıştır. Sektör iyileşmek için uzun bir yola girse dahi, muhtemelen bu süreçte gelişen olayların kalıcı etkiler ortaya çıkacaktır. Hem dijitalleşmede yaşanan hız hem de pandemi süreci, dijital göçebeleri ve turizmi bir araya getirerek "Digital Nomads Tourism" olarak bilinen yeni bir turizm modeli ortaya koymaktadır. Dijital göçebe turizm pazarı, erken hazırlık yapıldığı taktirde destinasyonlar için yeni bir pazar fırsatıdır (Wiranatha vd., 2020: 3). 
Bu çalışma, çevrimiçi kanallar üzerinden dijital göçebelerin destinasyon seçimi yaparken dikkate aldıkları kriterleri incelemek ve en geniş dijital göçebe platformlarının başında gelen nomadlist.com verilerine göre 2020 yılında en fazla tercih edilen destinasyonların nasıl kümelendiklerini ortaya koymak ve kümelere ait profilleri tanımlamaya çalışmaktır.

\section{KAVRAMSAL ÇERÇEVE}

\section{Dijital Göçebe Turizmi}

Dijital göçebe haline gelen insanların sayısındaki sürekli artışa ve bunların uluslararası ticaret, sosyal ve turizm ortamlarını şekillendirmedeki etkilerine rağmen (Richards, 2015) literatür bu konunun önemini çok fazla kavrayamamıştır. Dijital göçebelerle ilgili çoğu bilgi çevrimiçi veya gazete kaynaklarına dayanır. Dijital göçebe yaşam tarzının önemli bir parçasını seyahat eylemi oluşturduğu için, turizm çalışmaları dijital göçebelerin incelenmesi için doğal bir başlangıç noktasıdır (Hall vd., 2019: 438).

Ofis dışında çalışan ve işlerini bir ortak çalışma alanında dizüstü bilgisayar ve internet bağlantısı şeklinde elektronik ortam kullanarak tamamlayan ve turistik faaliyetler yapan turistlerin dijital göçebeler olarak adlandırıldığı yeni bir turist türünden bahsetmek mümkündür (Mulyana vd. 2020: 183). Dijital göçebeler, işlerine uzaktan devam edebilmek için yüksek teknolojiye gereksinim duyarlar, bu sebeple ya bu imkanları sunan ama yaşam maliyetinin çok yüksek olmadığı şehirleri ya da yine aynı imkanları sunabilen sosyal ve kültürel alanda zengin yerlerde olmayı tercih ederler. Dijital göçebeleri geleneksel turistlerden ayırt etmek gerekir. Geleneksel turistlere göre ekolojik ayak izlerinin daha küçük olduğu söylenebilir (Pecsek, 2018:10-11). Geleneksel turistler önceden belirlenmiş bir destinasyonu ziyaret etme ve eve dönmeden önce orada geçirdikleri zamanın tadını çıkarma niyeti içindedir (Kontogeorgopoulos, 2004: 101). Dijital göçebeler ise çalışma hayatlarını daha uzun süre konaklamalı seyahatlere dahil ederek yaşamaktadır. Dijital göçebeler aynı andan gezgin ve çalışan olarak seyahat eder ama bu geleneksel iş seyahati yapanlardan farklıdır. İş seyahatlerinde çalışan iş amacı ile iş ile ilgili olarak işletmenin belirlediği yere seyahat ederken ve masrafları işletme tarafından karşılanırken, dijital göçebeler gidecekleri yeri kendileri seçer, kalış sürelerini kendileri belirler ve masraflarını kendilerini karşılarlar. Özetle iş ile ilgili eylemlerden bağımsız olarak kendi tercihleri doğrultusunda seyahat ederler. Nomad List (2021) verileri dijital göçebelerin ne kadar süre kaldıklarına, bütçelerine ve bir yerde barınmanın karşılanabilirliğine bağlı olarak; pansiyonlarda, otellerde, Airbnb'lerde, kısa süreli apartmanlarda ve daha uzun süreli geleneksel uzun süreli kiralamalarda kalmayı tercih ettiklerini göstermektedir. Dijital göçebelerin kaldıkları alanlar genellikle tipik turistik bölgeler değildir. Bunun yerine, göçebeler bir yerde daha uzun süre kaldıkları için, biraz yerel ancak uluslararası alanlarda yaşamak istemekte, bu da genellikle merkezin biraz dışında, turistlerden uzaktaki alanlar olarak dikkat çekmektedir. Bölge için önemli olan, kafeler, restoranlar, oteller / Airbnb'ler ve çoğu için spor salonları gibi birçok tesisin olmasidır (www.nomadlist.com).

Turizm genellikle kısa yolculukla özdeşleşirken, göçebelerin yerel yaşamı anlamak ve buna dahil olmak için önemli miktarda zaman harcamasını gerektirir. Seyahat hızının yavaşlatılması aynı zamanda yerel insanlarla, daha derin seviyelerde etkileşim ve bağlantı kurma fırsatları da sağlar (Heitmann, 2011). Nitekim Putra ve Aigrachman (2016)'da yaptığı çalışmada ortak çalışma alanının, içinde zaman geçiren dijital göçebeler için yavaş turizmi destekleyerek yaratıcı turizmi ateşleyebileceği sonucuna ulaşılmıştır. Mouratidis (2018) de yaptığ1 çalışmada da dijital göçebelerin bir yerden diğerine seyahat ettikleri zaman aralığının birkaç haftadan başlayarak oldukça çeşitlilik gösterdiğini, ancak çoğunun aylık aralıkları tercih ettiği sonucu da bu 
bulgularla paralellik göstermektedir. Dijital göçebe turisti olarak ifade edilebilecek insanlar, süreleri geleneksel turizm hareketlerindeki kalış sürelerine göre daha uzun olan bir süre içerisinde, yerel ile etkin bir ilişki ve iletişim kurarak daha yavaş şekilde bir turizm deneyimi yaşamaktadır. Bir yandan uzaktan çalışarak işlerini yapıp para kazanırken, diğer taraftan farklı destinasyonlarda klasik konaklama sürelerinden daha uzun süreli kalışlarla, o bölgeyi deneyimlemek ve etkileşim kurarak keyifli vakit geçirmeyi amaçlarlar.

Wiranatha vd., (2020)'nın yaptığı çalışmada dijital göçebe turistinin ihtiyaçlarına cevap verebilmesi için destinasyonların sahip olması gereken nitelikler; hava durumu, internet erişimi dahil turistik noktaya uygun erişim, turist çekiciliği, konaklama ve yeme içme dahil ihtiyaç duyulacak imkanlar, güvenlik, doğal ve insan yapımı çevre, seyahat hizmetleri, özel etkinlikler, işletme teşvikleri, arkadaş ve akraba ziyareti ve hatıra olarak belirlenmiştir. Bu nitelikler geleneksel turistlerin beklentileri ile ortak noktalar içermekle birlikte uzaktan çalışma olanakları ile ilgili alt yapı ve üstyapı imkanlarına ilişkin beklentiler ile geleneksel turistten ayrılmaktadır.

Destinasyonlar için potansiyel turist olarak görülmeye başlanan dijital göçebeleri çekmek için onların destinasyon seçiminde hangi özellikleri aradıklarının araştırılması ve buna yönelik pazarlama bir süreci izlenmesi gerekir. Prabawa ve Pertiwi (2020)'de yaptıkları çalışmada dijital göçebelerin potansiyel olarak gelmelerini sağlayacak içsel ve dişsal motivasyon kaynaklarını tespit etmeye çalışmış ve dijital göçebeler için itici faktörleri; işle ilgili konularla ilgili motivasyon faktörleri ve ağın genişletilmesi olarak, çekici faktörleri ise; ilham verici yer, kalmak ve çalışmak için destekleyici yer, keyifli aktiviteler olarak bulmuştur. İtici faktör olarak söz konusu ağın genişletilmesi uzaktan çalışanlar için kendisi ile benzer işi yapan insanların olduğu daha geniş ağa sahip yerleri tercih etme motivasyonunu açıklarken, destinasyonun ilham verici olması ve çalışmalarını destekleyebileceği bir ortam sunması çekici faktör olarak dijital göçebeleri etkilemektedir. Destinasyonun sunduğu aktivite olanakları, bu aktivitelerin çeşitliliği ve zenginliği dijital göçebelerin bilgisayar başında geçirdikleri çalışma süreleri dışında kalan zamanlarını keyifli şekilde geçirmelerine imkân tanıyacak cazibede olmalıdır. Wirhanata vd., (2020)'nın yaptığı çalışmada ise dijital göçebeler için destinasyonun çekici faktörleri; (a) uygun yaşam maliyetleri, (b) yeterli olanaklar, (c) toplum misafirperverliği ve (d) haftalık etkinliklerin çeşitliliği olarak belirlenmiştir.

WYSE Travel Konfederasyonu'nun 2018 de yayınladıkları çalışmada dijital göçebenin sayısındaki artış ile birlikte daha çok sayıda ortak çalışma alanlarının ortaya çıktığını ve bu değişiminde yüksek hızda wifi bağlantı imkânı sunan destinasyonlarda hissedilmeye başladığını belirtmiştir (WYSE Travel Confederation, 2018). Dijital göçebeler uzaktan çalışan insanlar oldukları için hem sosyalleşmek hem işlerinde daha verimli olmak adına sosyal ağlar içinde yer almak, benzer işleri yapan insanlar ile ortak çalışma ve ortak yaşam alanlarında bulunmak isterler. Ortak çalışma alanları tüm dünyada oldukça yaygınlaşmıştır. Ortak çalışma ve ortak yaşam alanı, değerin birlikte yaratıldığı paylaşım ekonomisine aittir. Ortak çalışma, ofis topluluklarının, sanal çalışma, sanal ekipler, uygulama topluluklarının farklı unsurlarını entegre eder, ancak özellikle daha fazla esneklik, özerklik ve sosyal etkileşim fırsatları ile sektörler arası bir çalışma topluluğu sunar. (Bouncken ve Reuschl, 2018: 318). Dijital göçebeler, konumdan bağımsız bireylerin benzer fikirlere sahip toplulukları içinde gruplanma eğilimindedir. $\mathrm{Bu}$ nedenle, çalışma ve yaşam olanaklarını birleştiren kolektif iş-eğlence merkezleri, konukların kişilerarası ilişkilerini geliştirebilir (Chevtaeva, 2021: 203). Von Zumbusch ve Lalicic (2020)'in yaptığı çalışmada dijital göçebeler için önemli bir noktayı oluşturan birlikte yaşama ve ortak çalışma alanlarını refahını artırmaya yönelik olarak destinasyon yönetim organizasyonlarının uygulamasına yönelik teklifler ortaya koymaktadır. Bunlardan biri; topluluk yöneticilerinin, kullanıcıların birlikte yaşam alanları içinde ağ kurma ve sosyalleşme fırsatlarını en üst düzeye çıkarmak için girişimlerde bulunması gerektiği, bir diğeri ise kolaylaştırıcılardır. Birlikte yaşama 
mülklerinde, bunlar konaklama işletmeleri ya da farklı türde tesisler olsun, üyelere sırasıyla egzersiz, çalışma, sosyalleşme ve dinlenme için yeterli alan ayrılmalı ve bu sayede tasarımının aslında refahı teşvik ettiğinden emin olunmalıdır.

Kitlesel turizmin aksine dijital göçebe turistleri yerel ile daha fazla iletişim kurar. Dijital göçebe yaşam tarzı çoğunlukla izolasyona yol açmamaktadır. Valenduc ve Vendramin (2016) yaptıkları araştırmada dijital göçebe yaşam tarzlarının duygusal bağları güçlendirmek ve aidiyeti empoze etmek için yüz yüze etkileşimlere dayandığını vurgulamaktadır. Dijital göçebelerin çoğu kolayca ilişki kurabilecekleri diğer dijital göçebelerle tanışmanın avantajını önemserler ((Valenduc ve Vendramin, 2016). Bu nedenle de destinasyon seçimi yapmadan önce dijital göçebelerin üye oldukları çevrimiçi platformlar ve ağlar üzerinden iletişim kurar ve bu platformlarda yer alan yorumları dikkate alırlar. Dijital göçebelere yönelik olarak paylaşım yapan bloglar ve çevrimiçi kanallar sundukları seyahat önerileri ve görüntüde çok cazip görünen yaşam tarzları ile gençlerin ilgisini çekmeyi başarmakta ve bu yaşam tarzına olan ilgiyi artırmaktadır.

WYSE Seyahat Konfederasyonu (2018) dünyadaki dijital göçebelerin sayısının 2035'te 1 milyarı aşacağını söylemiştir. Pandemi sürecinin de bu büyümeyi hızlandıracağı düşünüldügüünde henüz bu pazara girmemiş ülkeler için oldukça iştah açıcı bir durum ortaya çıkmaktadır. Bugün bu pastadan pay alan, çevrimiçi platformlarda veya medyada yer alan köşe yazılarında dijital göçebeler için popüler olan, destinasyonlar arasında; Belarus, Singapur, Slovenya, Estonya, Macaristan gibi ülkeler gelmektedir. Covid süreci ile birlikte uzaktan çalışanların sayısındaki hızlı artış hükümetlerin de dikkatini çekmiş olacak ki sadece 2020 yılı içerisinde 10'dan fazla destinasyonun başbakanı ya da üst düzey politikacıları tarafından dijital göçebe turizmi ile ilgili attıkları adımları deklere eden ve davet niteliğinde açıklamalar yapılmıştır. Bu ülkelerden bazılarl; Bermuda, Cayman Adalarl, Gürcistan, Barbados, Antigua ve Barbuda, Dubai, Hırvatistan ve Türkiye'dir. Bu ülkelerin başbakan veya üst düzey politikacılarının yaptıkları açılamalarda dijital göçebe talebini artırmak adına üzerinde durdukları konulardan bazıları; dijital göçebe vizesi, gelişmiş altyapı, küresel bağlanabilirlik, hızlı internet, sanal çalışma programları, çok kültürlülük ve misafirperverlik, tarihi ve kültürel çekicilikler, sosyal aktiviteler, güvenlik ve emniyettir.

\section{Dijital Göçebe Platformu Nomad List}

2007'nin ilk göçebe dalgasından sonra, uzun bir süre durgunluk yaşanmış, daha sonrasında teknolojik gelişmelere paralel olarak uzaktan çalışanların sayısında ciddi artışlar yaşanmıştır. Dünyanın dört bir yanındaki milyonlarca teknoloji çalışanı için uzaktan çalışma normal hale gelmeye başlamış, ikinci göçebelik dalgası 2014 yılında Nomad List'in piyasaya sürülmesi için mükemmel bir ortam yaratmıştır. Nomad List Temmuz 2014'te piyasaya girmiş ve Product Hunt, Hacker News'te en üst sıralara çıkmış, Reddit'in ön sayfasında yer almış ve New York Times, CNN, BBC, The Guardian, CNBC ve diğer birçok büyük medya kuruluşunda sürekli olarak yer almış bir dijital göçebe platformudur (www.nomadlist.com).

Platform dijital göçebeler için kurulmuş ve misyonu uzaktan çalışma ile sağlanan küresel hareket özgürlüğünü teşvik etmek olan çevrimiçi bir oluşumdur. Nomad List dijital göçebelere, gidecekleri şehirlerde ortak çalışma alanları bulmak, belirli bir ayda bir şehrin ne kadar sıcak olduğunu görmek, belirli iklime sahip yerleri aramak, o şehre daha önce seyahat etmiş diğer dijital göçebelerle iletişim kurmak ve onların paylaştıkları yorumları okumak gibi birçok içerik sunmaktadır. Nomad List 2014 yılından beri 93.000.000'den fazla ziyaret almıştır. Nomad List'in kendi sayfasındaki verilere göre 2019 yllında 1.000.000'den fazla kişi belirli süre ile yaşamak ve uzaktan çalışmak için, 195 farklı ülkede 1.354 şehir arasından bu platform üzerinden seçim yapmıştır (www.nomadlist.com). 
Sistemde aynı yerde diğer insanlarla tanışmak ve her gün Slack'te sohbet etmek için seyahatlerini kaydeden 10.000'den fazla kişilik üye tabanı bulunmaktadır. Bu üyelerin birçoğu aynı zamanda gerçek hayatta düzenli buluşmalar organize etmektedir. Nomad List topluluğunun amaçlarından biri de bu şekilde uzaktan çalışan bir işçi olmayı daha az izole hale getirmektir. Ücretli bir üyelik sistemi olan Nomad List bu şekilde platform içinde insanların gidecekleri şehirleri bulmalarına yardımcı olması amacı ile sunduğu verileri elde etmede kullandığı sistemin gelişimini finanse etmektedir.

Demografik ve sağlık bilgileri gibi kriterler için Birleşmiş Milletler (BM), Dünya Sağlık Örgütü (WHO), Uluslararası Para Fonu (IMF), Dünya Bankası'nın halka açık veri setlerine ve ayrıca hava durumu, hava kalitesi ve trafik yoğunluğu gibi kriterler için genel uygulama programlama ara yüzleri, güvenlik verileri için en son mevcut suç istatistiklerinin yanı sıra her yer için silahlı çatışma ve siyasi istikrar verilerini kullanmaktadır. Diğer kriter skorlarını belirlemede de farklı veri tabanlarından aldığı güncel veriler ve dijital göçebelerin yorumlarını kullanmaktadır. Tüm veriler sürekli olarak kaydedilerek normalleştirilmektedir. Nomad List günlük değişebilen verileri de (sıcaklıklar, nem, internet hızları, döviz kurları vb. dahil) güncellemeye devam etmekte ve sitede yer alan puanlamalarda her 10 dakikada bir yeniden oluşturulmaktadır. Verilerin sadece yorumlara dayanmıyor olması objektiflik açısından değer ve güven yaratmaktadır. Bu sayede üyeler ve sayfayı ziyaret edenler en güncel ve doğru veriye ulaşabilmektedir (www.nomadlist.com).

\section{METODOLOJi}

\section{Amaç ve Yöntem}

Pandemi süreci ile hızlanan dijitalleşme ve uzaktan çalışma sayılarındaki artış düşünüldüğünde, konunun turizm açısından ele alınması önem taşımaktadır. Bu konuda çok sınırlı sayıda araştırma olduğu düşünüldüğünde, dijital göçebelerin destinasyon seçerken hangi kriterleri dikkate aldığı, itici ve çekici faktörlerin neler olduğu ve bu faktörlerin ne derece önemli olduğu, Dünya'da en fazla talep göre dijital göçebe destinasyonları ve bu destinasyonların ortak özelliklerinin neler olduğunu araştırmak konunun turizm açısından olgunlaştırılması ve literatüre katkı sağlaması açısından önemlidir.

$\mathrm{Bu}$ çalışma dijital göçebe hareketliliğinin turizm araştırmaları için kurumsallaşmasını kolaylaştırmak açısından önemlidir. Çalışma, dijital göçebelerin destinasyon seçiminde dikkate aldıkları destinasyon seçim kriterlerine ait skorlara göre destinasyonların nasıl kümelendiklerini tespit etmek ve kriterler bazında kümelerin özelliklerini tanımlamaktır. Araştırmada destinasyonların dijital göçebelerin destinasyon seçim kriterleri skorlarındaki benzerliklere göre nasıl kümelendiğini belirlemek için SPSS programı üzerinde $\mathrm{K}$ ortalamalar kümeleme analizi yapılmıştır. K-means algoritmasının temel mantığı $\mathrm{n}$ adet veri nesnesinden oluşmuş bir veri setini, k adet giriş parametresi sayısı kadar kümeye bölümlemektir. Amaç, yapılan işlem sonucunda elde edilen kümelerin, küme içi benzerliklerinin maksimum, kümeler arası benzerliklerinin minimum hale getirmektir (Çolak vd., 2016: 316). Çalışmada küme sayısını belirlemede kullanılan eşitlik aşağıdaki gibidir (Allahverdi ve Alagöz, 2019: 450):

$$
k=\sqrt{\frac{n}{2}}
$$

Bu eşitliğin küçük örneklem gruplarında kullanılması önerilir (Allahverdi ve Alagöz, 2019: 450). $\mathrm{Bu}$ çalışmada örneklem sayısı 2020'de Nomadl Lİst verilerine göre en fazla talep gören 20 
destinasyonu kapsadığı için küme sayısının belirlenmesinde kullanılması uygun olacaktır. Bu eşitliğe göre $n=20$ ve yaklaşık küme sayısı 3 olur.

\section{Araştırma Verilerinin Toplanması}

Araştırma verilerin toplanmasında ikincil veri kaynakları kullanılmıştır. Verilerin toplanmasında 2020 yılında 1 milyondan fazla kişinin dijital göçebe destinasyonu bulmak için kullandığı, 2014 yılından beri 93 milyondan fazla ziyaret alan Nomad List verileri kullanılmıştır. Nomad List verilerinin bilimsel çalışmalarda kullanılmasına kaynak göstermek koşulu ile izin verdiğini sayfasında beyan etmiştir. Araştırma Nomad List 'de 2020 yılında en fazla ziyaret alan 20 destinasyon ve yine bu 20 destinasyonun Nomad List' de belirtilen destinasyon seçim kriterleri skorları kullanılarak yapılmıştır. Nomad List'de her destinasyon için belirtilen ve dijital göçebelerin destinasyon seçerken dikkate aldıkları genel kriterler; İnternet hızı, Ücretsiz Wifi, İngilizce Konuşma, Eğitim Seviyesi, Startup, Gelir Düzeyi, Maliyet Uygunluğu, Güvenlik, Trafik Güvenliği, Yürünebilirlik, İnsan Yoğunluğu, Sağlık Hizmeti, Yaşam Kalitesi Düzeyi, Aile, Mutluluk, Barış, Konuşma Özgürlüğü, Eğlence, Gece Hayatı, Sıcaklık, Hava Kalitesi (Yıllık), Nem, A/C Isıtma Sistemleri, Diğer Dijital Göçebeler Tarafından Beğenilme, Kadınlara Karşı Hoşgörü, LGBTQ Karşı Tutum, Yabancılara Dost, Irksal Hoşgörü şeklinde sıralanmaktadır.

Araştırmada kümeleme analizi için Nomad List verilerine göre 2020 yılında en fazla tercih edilen 20 destinasyonun 21.01.2021 tarihli yukarıdaki kriterlere ait skorları kullanılmıştır. Dijital göçebelerin çok farklı şehirlerden çok farklı şehirlere hareket eden bir kitle olduğu ve geniş bir alanı kapsadığı düşünüldüğünde, ikincil veri kullanmanın önemli avantajlarından biri olan verilerin genişliği bu çalışmada önem taşımaktadır.

\section{ARAŞTIRMA BULGULARI}

$\mathrm{Bu}$ kısımda öncelikle araştırmaya dahil edilen 20 destinasyonun Nomad List'deki 2020 sıralamaları ve genel skorları verilmiş ardından yapılan kümeleme analizi sonuçları ve kümelere ait ortamalar incelenmiştir.

\section{Destinasyonların Nomad List Sıralama ve Skorlarına İlişkin Değerlendirme}

Araştırmada Nomad List verilerinden elde edilen, 2020 yılı içerisinde en çok tercih edilen 20 destinasyon ve bu destinasyonların destinasyon seçim kriterlerine ilişkin genel ortalamaları aşağıda Tablo 1'de verilmiştir. Bu veriler, büyümeden bağımsız olarak 2020'de gerçekleştirilen yolculuk sayılarına göre en çok ziyaret edilen destinasyonları vermektedir.

Tablo 1 incelendiğinde, 2020 yılı pandemi sürecinde gerçekleştirilen dijital göçebe seyahatlerinin en fazla gerçekleştiği ilk destinasyon Londra olmasına rağmen, Londra'nın genel puanının kendisinden sonra gelen 8 destinasyondan daha düşüktür. Londra'dan hemen sonra ikinci sırada en yüksek ortalamaya sahip destinasyon olarak Lisbon (4.79) gelmektedir. Dijital göçebe denilince ilk akla gelen destinasyonların başında gelen Canggu $(4,70)$ ise 2020 yılında dijital göçebe seyahatlerinin en fazla olduğu üçüncü destinasyon olmuştur. Ortalamalar açısından en düşük ortalamaya sahip destinasyon olan San Francisco (3,28), 2020 yılında en çok ziyaret edilen 14. destinasyon olmuştur. Genel ortalaması 3,30 olan Ho Chi Minh City (Vietnam) ise 2020 yılında en çok ziyaret edilenler sıralamasında 20. sırada yer almıştır. 
Tablo 1. Nomad List Verilerine Göre 2020 yılında En çok Tercih Edilen 20 Destinasyon

\begin{tabular}{rlccc}
\hline Sira & Destinasyon & $\begin{array}{c}\text { Genel } \\
\text { Puan }\end{array}$ & Sira Destinasyon & Genel Puan \\
\hline 1 Londra & 4,11 & 11 Playe Del Carmen & 4,35 \\
2 & Lisbon & 4,79 & 12 Barcelona & 4,22 \\
3 Canggu, Bali & 4,70 & 13 Amsterdam & 3,62 \\
4 Bangkok & 3,99 & 14 San Francisco & 3,28 \\
5 Berlin & 4,39 & 15 Los Angeles & 3,34 \\
6 & Mexico City & 4,38 & 16 İstanbul & 4,00 \\
7 & Chiang Mai & 4,22 & 17 Buenos Aires & 4,01 \\
8 & New York City & 3,76 & 18 Kuala Lumpur & 3,68 \\
9 & Paris & 3,42 & 19 Budapeşte & 3,87 \\
10 & Singapur & 4,22 & 20 Ho Chi Minh City & 3,30 \\
\hline
\end{tabular}

Kaynak: Nomad List verileri kullanılarak araştırmacı tarafından hazırlanmıştır.

İstanbul'a bakıldığında, dijital göçebeler tarafından 2020 yılı içinde en çok ziyaret edilen 16. destinasyon olduğu görülmektedir. İstanbul'un genel ortalaması $(4,00)$, bu 20 destinasyon arasında 9 destinasyondan daha yüksek bir ortalamaya sahiptir. Dünya'da 1354 destinasyon arasından pandemi koşullarının hüküm sürdüğü 2020 yılı içinde en çok tercih ziyaret edilen 16. destinasyon olması dijital göçebe turizmi potansiyeli açısından önemlidir.

\section{K-Means Kümeleme Analizine İlişkin Bulgular}

Araştırma yöntemi kısmında 3 olarak belirlenen küme sayısı dikkate alınarak SPSS programında k-means kümeleme analizi yapılmıştır. 20 destinasyona ait 27 farklı kritere ilişkin skorlar kullanılarak yapılan kümeleme analizi sonucunda son küme merkezleri Tablo 2'deki şekilde oluşmuştur.

Araştırmaya dahil edilen 20 destinasyonun dijital göçebelerin değerlendirmelerine göre nasıl kümelendiklerini gösteren veriler Tablo 3'de görülmektedir. Tablo 3'e göre, Londra, Berlin, New York, Paris, Singapur, Amsterdam, San Francisco ve Los Angeles bir küme; Bangkok, Chiang Mai, Kuala Lumpur, İstanbul, Ho Chi Minh City bir küme; Canggu- Bali, Mexico City, Playe Del Carmen, Barcelona, Buenos Aires, Budapeşte, Lisbon ise bir küme oluşturmaktadır.

Kümelere göre ortalamaların dağılımının daha net ve kümelerin öne çıkan karakteristik özelliklerinin daha kolay görülebilmesi için dağılıma ilişkin grafik Şekil 1'de verilmiştir. Kümelere ait isimlendirme yapilırken dikkate alınan temel kriter, kümede yer alan destinasyonların hangi kriterlerde daha yüksek veya daha düşük ortalamalarla öne çıtığıdır. Bir destinasyonun pahalı ya da ucuz olması (Nomadlist bu verileri Uluslararası veri tabanlarindan almaktadır) ve yabancılara karşı olumlu tutum içinde olması veya olmaması gibi iki ana kriter küme ortalamalarında dikkat çekmektedir. Dijital göçebeler destinasyon seçerken öncelikle bütçelerine göre ucuz ya da pahalı destinasyon seçme eğilimindedir. Nomadlist platformu incelendiğinde de süzme kriterleri arasında en üst sıralarda "ucuz destinasyonlar" kriteri dikkat çekmektedir. Aynı zamanda da toleransın yüksek olduğu destinasyonları tercih ederler. Bu nedenle bu araştırma da bu iki temel kriter dikkate alınarak kümeler isimlendirilmiştir. 
Tablo 2. K-Means Kümeleme Analizinden Elde Edilen Son Küme Merkezleri

\begin{tabular}{lccc}
\hline \multirow{2}{*}{ Destinasyon Seçiminde Etkili Kriterler } & \multicolumn{3}{c}{ Kümeler } \\
\cline { 2 - 4 } & $\mathbf{1}$ & $\mathbf{2}$ & $\mathbf{3}$ \\
\hline Güvenlik & 2,46 & 2,91 & 3,52 \\
Ücretsiz Wifi & 4,19 & 3,64 & 3,29 \\
İngilizce Konuşma & 4,60 & 2,60 & 3,20 \\
Eğitim Seviyesi & 4,23 & 3,05 & 3,25 \\
Startup Toplantıları & 3,51 & 2,44 & 2,77 \\
Yerel Halkın Gelir Düzeyi & 4,70 & 1,50 & 1,70 \\
Yaşam maliyeti uygunluğu & 1,94 & 4,80 & 4,88 \\
Trafik Güvenliği & 3,00 & 2,00 & 3,00 \\
Yürünebilirlik & 5,00 & 4,50 & 4,70 \\
İnsan Yoğunluğu & 3,40 & 4,00 & 4,20 \\
Sağlık Hizmeti & 3,80 & 2,79 & 1,57 \\
Yaşam Kalitesi Düzeyi & 4,03 & 3,66 & 3,99 \\
Aile & 3,86 & 3,00 & 3,56 \\
Mutluluk & 4,32 & 3,09 & 3,57 \\
Barış & 3,20 & 3,10 & 2,90 \\
Konuşma Özgürlüğü & 3,95 & 2,28 & 3,18 \\
Eğlence & 4,30 & 3,90 & 4,40 \\
Gece Hayatı & 4,78 & 3,63 & 4,00 \\
Sıcaklık (Aralık-Şubat) & 2,40 & 3,40 & 3,10 \\
Hava Kalitesi (Yıllık) & 3,85 & 2,82 & 3,70 \\
Nem & 2,41 & 2,40 & 2,41 \\
İklimlendirme Sistemleri & 3,80 & 2,90 & 3,80 \\
Diğer Dijital Göçebeler Tarafından & 4,20 & 4,10 & 4,30 \\
Beğenilme & & & \\
Kadınlara Karşı Hoşgörü & 4,13 & 3,00 & 3,57 \\
LGBTQ Karşı Tutum & 4,60 & 1,50 & 4,70 \\
Yabancllara Dost & 4,00 & 3,50 & 4,30 \\
Irksal Hoşgörü & 4,00 & 2,00 & 3,00 \\
\hline
\end{tabular}

Tablo 3. K-Means Kümeleme Analizi Sonucu Destinasyonların Kümelere Göre Dağılımı

\begin{tabular}{lc}
\hline Küme & Destinasyonlar \\
\hline Küme 1 & ndra, Berlin, New York, Paris Singapur, Amsterdam, San Francisco, Los Angeles \\
Küme 2 & Bangkok, Chiang Mai, Kuala Lumpur, İstanbul, Ho Chi Minh City \\
Küme 3 & $\begin{array}{l}\text { Canggu- Bali, Mexico City, Playe Del Carmen, Barcelona, Buenos Aires, Budapeşte, } \\
\text { Lisbon }\end{array}$ \\
\hline
\end{tabular}

Şekil 1'de verilen kümelerde yer alan destinasyonların sahip oldukları küme ortalamalarına bakıldığında 1 nolu küme gelir düzeyi ve yaşam maliyetinin yüksekliği ile pahalı bir destinasyon imajı ortaya koyarken aynı zamanda ırksal hoşgörü, yabancılara dost, kadınlara karşı hoşgörü vb. kriterlerde sahip olduğu yüksek ortalama ile toleransı yüksek destinasyon imajı çizdiği için 
bu kümeye "Yüksek Toleranslı-Lüks Dijital Göçebe Destinasyonları" adı verilmiştir. 2 nolu kümenin gelir düzeyi ve yaşam maliyeti ortalamaları yerel halkın ortalamanın altında bir gelir düzeyinde olduğunu ve yaşam maliyetinin çok yüksek olmadığını göstermektedir. Bunun yanı sıra tolerans boyutlarındaki ortalamaları diğer iki kümeye göre daha düşüktür. Bu özellikleri dikkate alınarak 2 nolu kümeye "Düşük Toleranslı-Ekonomik Dijital Göçebe Destinasyonları" adı verilmiştir. Son olarak 3 nolu kümeye ilişkin ortalamalara bakıldığında yaşam maliyeti ve gelir düzeyi açısından ekonomik olduğu aynı zamanda ırksal hoşgörü, kadınlara karşı tutum ve yabancılarla dost gibi kriterlerdeki yüksek ortalama ile turistlere karşı toleransı yüksek bir küme olduğu için bu kümeye de "Yüksek Toleransl1-Ekonomik Dijital Göçebe Destinasyonları" adı verilmiştir.

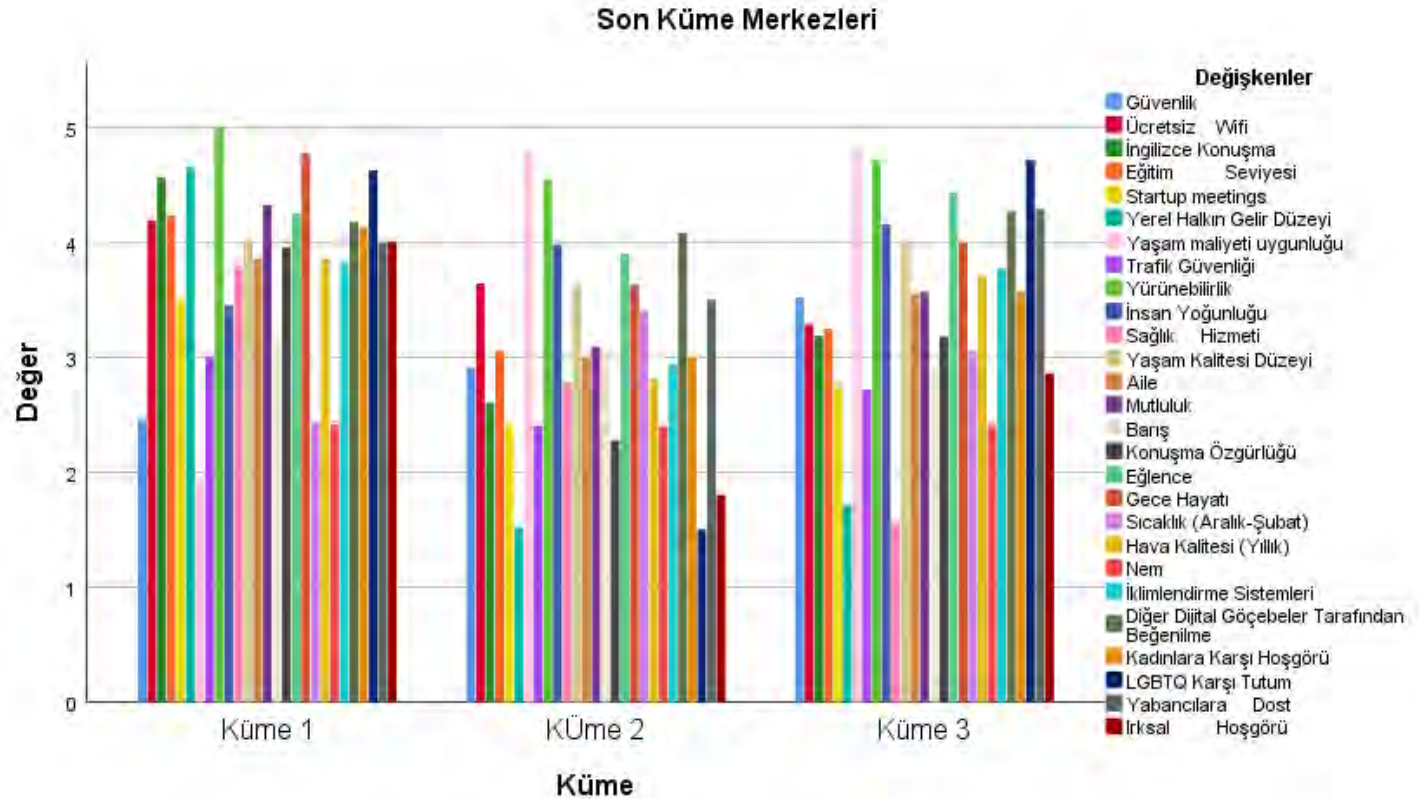

Şekil 1. K-Means Kümeleme Analizinden Elde Edilen Son Küme Merkezleri

Tablo 4. Destinasyonların Oluşturduğu Kümelerin İsimlendirilmesi

\begin{tabular}{lll}
\hline Kümeler & Destinasyonlar & Küme Adı \\
\hline Küme 1 & $\begin{array}{l}\text { Londra, Berlin, New York, Paris Singapur, } \\
\text { Amsterdam, San Francisco, Los Angeles }\end{array}$ & $\begin{array}{l}\text { Yüksek Toleranslı-Lüks Dijital Göçebe } \\
\text { Destinasyonları }\end{array}$ \\
Küme 2 & $\begin{array}{l}\text { Bangkok, Chiang Mai, Kuala Lumpur, } \\
\text { İstanbul, Ho Chi Minh City }\end{array}$ & $\begin{array}{l}\text { Düşük Toleranslı-Ekonomik Dijital } \\
\text { Göçebe Destinasyonları }\end{array}$ \\
Küme 3 & $\begin{array}{l}\text { Canggu- Bali, Mexico City, Playe Del } \\
\text { Carmen, Barcelona, Buenos Aires, } \\
\text { Budapeşte, Lisbon }\end{array}$ & $\begin{array}{l}\text { Yüksek Toleranslı-Ekonomik Dijital } \\
\text { Göçebe Destinasyonları }\end{array}$ \\
\hline
\end{tabular}

Dijital göçebelerin 2020 yılında en çok ziyaret ettiği 20 destinasyon, kümeleme analizi sonucunda 3 gruba ayrılmıştır. Bu grupların değişkenlere ilişkin minimum, maksimum ve ortalama değerlerine bakılarak kümelere ilişkin bir değerlendirme yapıldığında Tablo 5'deki sonuçlara ulaşılmaktadır. Tabloda dijital göçebeler için en önemli kriterlerden biri olan ücretsiz internet erişimi ortalamalarına bakıldığında, Yüksek toleranslı-lüks dijital göçebe destinasyonları 
(Londra, Berlin, New York, Paris Singapur, Amsterdam, San Francisco, Los Angeles) ve düşük toleranslı-ekonomik dijital göçebe destinasyonlarında (Bangkok, Chiang Mai, Kuala Lumpur, İstanbul, Ho Chi Minh City) en düşük ve en yüksek değerlerin 2,50 ve 5,00 arasında değiştiği yüksek toleranslı-ekonomik dijital göçebe destinasyonlarında (Canggu- Bali, Mexico City, Playe Del Carmen, Barcelona, Buenos Aires, Budapeşte, Lisbon) ise en yüksek değerin 4,00 olduğu görülmektedir. Ücretsiz internet erişimi ortalamasının en yüksek olduğu küme lüks destinasyonlar kümesidir.

Dijital göçebeler için destinasyon seçiminde önemli bir diğer kriter ise gidecekleri yerdeki halkın yabancı dil bilgisidir. Uluslararası iletişim dili olarak kullanılan İngilizcenin yerel halk tarafından biliniyor olması, dijital göçebelerin destinasyon seçiminde değerlendirmeye aldıkları bir kriterdir. Kümelerin İngilizce konuşma ortalamalarına bakıldığında en yüksek ortalamanın 4.19 ile yüksek toleranslı-lüks destinasyonlara ait olduğu, en düşük ortalamanın ise 2,66 ile D.T. ekonomik destinasyonlara ait olduğu görülmektedir.

Dijital göçebelerin destinasyon seçerken merak ettikleri bir diğer husus ise destinasyondaki halkın eğitim seviyesidir. Kümelerin eğitim sevilerine ilişkin ortalamalarda 4,23 ile yüksek toleranslı lüks destinasyonların en yüksek ortalamaya sahip olduğu görülürken, düşük toleransl1- ekonomik destinasyonlar 2,83 ortalama ile diğer iki kümenin gerisindedir. Startup'lar dijital göçebeler için yeni işler ve ilişkiler geliştirmede oldukça önemlidir. Bu anlamda destinasyon seçimi yaparken gidecekleri yerde diğer dijital göçebelerin de katıldığı startup etkinliklerinin varlığı, dijital göçebelerin seçim yaparken dikkate aldığı bir kriterdir. Kümelerin ortalamalarına bakıldığında yüksek toleranslı lüks destinasyonlar en düşük 2,50 ve en yüksek 4,70 olmak üzere 3,51 ortalama ile diğer kümelerin önündedir. Bu değişkende en düşük ortalama yine 2,48 ile düşük toleranslı ekonomik destinasyonlardadır.

Dijital göçebeler, işlerini uzaktan yapmaya devam edecekleri yeri seçerken, seçecekleri destinasyondaki gelir seviyesi ve o şehirde yaşamanın maliyeti önemli bir belirleyicidir. Dijital göçebeler, elde ettikleri gelir ile yaşamlarını devam ettirebilecekleri destinasyonlar seçerler. Bu nedenle seçecekleri destinasyondaki gelir düzeyi ve yaşam maliyeti önemli bir belirleyici olabilir. Kümelerin gelir düzeyi ve yaşam maliyeti ortalamalarına bakıldığında yüksek toleranslı-lüks destinasyonlar kümesinde yer alan Londra, Berlin, New York, Paris Singapur, Amsterdam, San Francisco ve Los Angeles halkın gelir düzeyi ortalamasında $(4,65)$ en yüksek ortalamaya sahip kümedir. Bunun yanı sıra bu küme en düşük yaşam maliyeti ortalaması ile $(1,94)$, diğer kümelere göre yaşam maliyetinin en yüksek olduğu kümedir. Düşük toleransl1-ekonomik destinasyonlara bakıldığında diğer kümelere göre 1 ve 2 arasında değişen en düşük gelir düzeyi ortalamasına $(1,32)$ sahip kümedir. Bununla beraber 4 ile 5 arasında değişen 4,80 ortalaması ile yaşam maliyetinin uygunluğunun en yüksek olduğu kümedir. Yüksek toleransl1-ekonomik dijital göçebe destinasyonları kümesi de gelir ve maliyet kriterleri açısından ekonomik destinasyonlara yakın ortalamalara sahip olsa da az farkla ekonomik destinasyonlar kümesinden daha yüksek ortalamaya sahiptir.

Dijital göçebeler destinasyon seçerken, seçecekleri şehirdeki hoşgörü ve farklılıklara karşı tolerans düzeylerini önemserler. Aynı zamanda yabancılara karşı yaklaşım ve tutumda önemlidir. Kümelerin bu başlıklara ilişkin ortalamalarına bakıldığında diğer göçebeler tarafından beğenilme ortalamasının en yüksek olduğu küme 4,41 ile popüler dijital göçebe destinasyonlarının içinde olduğu yüksek toleransli-ekonomik destinasyonlar (Canggu- Bali, Mexico City, Playe Del Carmen, Barcelona, Buenos Aires, Budapeşte, Lisbon) kümesi olduğu görülür. Kadınlara karşı hoşgörü boyutunda ortalamalara bakıldığında birinci sırada 4,13 ile yüksek toleransl1-lüks destinasyonlar, ikinci sırada 3,57 ile yüksek toleransl1-ekonomik destinasyonlar, üçüncü sırada ise 3,00 ile düşük toleransl1-ekonomik destinasyonlar yer almaktadır. 
Tablo 5. Kümelere İlişkin Tanımlayıcı İstatistikler

\begin{tabular}{|c|c|c|c|c|c|c|c|c|c|c|c|c|}
\hline \multirow{3}{*}{ Değişkenler } & \multicolumn{4}{|c|}{$\begin{array}{c}\text { Lüks Dijital Göçebe } \\
\text { Destinasyonları }\end{array}$} & \multicolumn{4}{|c|}{$\begin{array}{c}\text { Ekonomik Dijital Göçebe } \\
\text { Destinasyonları }\end{array}$} & \multicolumn{4}{|c|}{$\begin{array}{c}\text { Hoşgörülü Dijital Göçebe } \\
\text { Destinasyonları }\end{array}$} \\
\hline & & & & St. & & & & St. & & & & St. \\
\hline & Min & Max & Ort. & Sapma & Min & $\operatorname{Max}$ & Ort. & Sapma & Min & $\operatorname{Max}$ & Ort. & Sapma \\
\hline Ücretsiz Wifi & 2,50 & 5,00 & 4,19 & 0,884 & 2,70 & 5,00 & 3,92 & 0,823 & 2,60 & 4,00 & 3,09 & 0,524 \\
\hline İngilizce Konuşma & 2,50 & 5,00 & 4,56 & 0,904 & 1,90 & 3,00 & 2,66 & 0,451 & 2,60 & 5,00 & 3,14 & 0,873 \\
\hline Eğitim Seviyesi & 3,71 & 4,41 & 4,23 & 0,256 & 2,29 & 3,17 & 2,83 & 0,341 & 2,79 & 3,92 & 3,40 & 0,474 \\
\hline Startup Toplantıları & 2,50 & 4,70 & 3,51 & 0,685 & 2,20 & 2,70 & 2,48 & 0,228 & 2,50 & 3,50 & 2,74 & 0,378 \\
\hline $\begin{array}{l}\text { Yerel Halkın Gelir } \\
\text { Düzeyi }\end{array}$ & 4,00 & 5,00 & 4,65 & 0,441 & 1,00 & 2,00 & 1,32 & 0,460 & 1,00 & 2,70 & 1,86 & 0,516 \\
\hline $\begin{array}{l}\text { Yaşam maliyeti } \\
\text { uygunluğu }\end{array}$ & 1,00 & 4,00 & 1,94 & 0,918 & 4,00 & 5,00 & 4,80 & 0,447 & 3,80 & 5,00 & 4,88 & 0,454 \\
\hline Trafik Güvenliği & 3,00 & 3,00 & 3,00 & 0,000 & 2,00 & 3,00 & 2,20 & 0,447 & 2,00 & 3,00 & 2,86 & 0,378 \\
\hline Yürünebilirlik & 5,00 & 5,00 & 5,00 & 0,000 & 2,70 & 5,00 & 4,54 & 1,029 & 3,00 & 5,00 & 4,71 & 0,756 \\
\hline İnsan Yoğunluğu & 1,00 & 5,00 & 3,45 & 1,386 & 2,40 & 5,00 & 3,98 & 1,397 & 0,00 & 4,00 & 2,01 & 2,000 \\
\hline Sağlık Hizmeti & 3,11 & 4,55 & 3,80 & 0,478 & 1,84 & 3,78 & 3,03 & 0,861 & 0,00 & 3,05 & 1,39 & 1,341 \\
\hline Yaşam Kalitesi & 3,47 & 4,43 & 4,03 & 0,300 & 3,33 & 4,00 & 3,68 & 0,262 & 3,69 & 4,25 & 3,97 & 0,204 \\
\hline Düzeyi & & & & & & & & & & & & \\
\hline Aile & 3,50 & 4,19 & 3,86 & 0,206 & 2,62 & 3,45 & 3,04 & 0,384 & 3,25 & 4,01 & 3,53 & 0,265 \\
\hline Mutluluk & 3,87 & 4,83 & 4,32 & 0,303 & 2,46 & 3,85 & 3,31 & 0,614 & 2,58 & 4,03 & 3,40 & 0,710 \\
\hline Barış & 2,50 & 4,00 & 3,16 & 0,674 & 2,00 & 3,80 & 2,76 & 0,680 & 2,00 & 4,20 & 3,13 & 0,896 \\
\hline $\begin{array}{l}\text { Konuşma } \\
\text { Özgürlüğü }\end{array}$ & 2,00 & 4,95 & 3,95 & 0,862 & 0,58 & 2,56 & 2,06 & 0,842 & 2,24 & 4,38 & 3,33 & 0,911 \\
\hline Eğlence & 2,00 & 5,00 & 4,25 & 1,035 & 3,00 & 4,50 & 3,90 & 0,548 & 4,00 & 5,00 & 4,43 & 0,535 \\
\hline Gece Hayatı & 4,10 & 5,00 & 4,78 & 0,417 & 0,68 & 5,00 & 4,14 & 1,932 & 1,58 & 5,00 & 3,64 & 1,386 \\
\hline $\begin{array}{l}\text { Sicaklık (Aralık- } \\
\text { Şubat) }\end{array}$ & 2,00 & 5,00 & 2,44 & 1,050 & 2,50 & 5,00 & 3,50 & 1,369 & 1,90 & 5,00 & 2,99 & 1,397 \\
\hline $\begin{array}{l}\text { Hava Kalitesi } \\
\text { (Yillık) }\end{array}$ & 3,50 & 4,00 & 3,85 & 0,169 & 1,70 & 4,00 & 2,84 & 0,974 & 2,30 & 4,00 & 3,69 & 0,618 \\
\hline $\mathrm{Nem}$ & 2,30 & 2,50 & 2,41 & 0,083 & 2,30 & 2,40 & 2,38 & 0,045 & 2,30 & 2,50 & 2,43 & 0,095 \\
\hline $\begin{array}{l}\text { İklimlendirme } \\
\text { Sistemleri }\end{array}$ & 2,00 & 5,00 & 3,83 & 1,162 & 2,50 & 5,00 & 3,18 & 1,033 & 2,70 & 5,00 & 3,60 & 1,025 \\
\hline $\begin{array}{l}\text { Diğer D. Göçebeler } \\
\text { Tarafından } \\
\text { Beğenilme }\end{array}$ & 3,80 & 5,00 & 4,18 & 0,515 & 3,70 & 4,00 & 3,88 & 0,130 & 3,90 & 5,00 & 4,41 & 0,549 \\
\hline $\begin{array}{l}\text { Kadınlara Karşı } \\
\text { Hoşgörü }\end{array}$ & 3,41 & 5,00 & 4,13 & 0,609 & 2,00 & 4,00 & 3,00 & 1,000 & 3,00 & 4,00 & 3,57 & 0,535 \\
\hline $\begin{array}{l}\text { LGBTQ Karşı } \\
\text { Tutum }\end{array}$ & 2,00 & 5,00 & 4,63 & 1,061 & 1,00 & 4,00 & 2,00 & 1,225 & 1,50 & 5,00 & 4,36 & 1,314 \\
\hline Yabancilara Dost & 3,00 & 5,00 & 4,00 & 0,926 & 3,00 & 5,00 & 3,90 & 0,742 & 3,00 & 5,00 & 4,00 & 0,817 \\
\hline Irksal Hoşgörü & 3,00 & 5,00 & 4,00 & 0,535 & 0,00 & 3,00 & 1,80 & 1,095 & 2,00 & 4,00 & 2,86 & 0,900 \\
\hline
\end{tabular}

Dijital göçebeler destinasyon seçerken, şehirdeki insan yoğunluğunu da dikkate alırlar. Bu açıdan bakıldığında yüksek toleranslı-ekonomik destinasyonlar kümesinde yer alan Canggu- Bali, Mexico City, Playe Del Carmen, Barcelona, Buenos Aires, Budapeşte ve Lisbon yoğunluk ortalamasının en düşük olduğu küme iken $(\mathrm{Ort}=2,01)$ düşük toleransl-ekonomik destinasyonların oluşturduğu küme en yüksek yoğunluk ortalamasına $(\mathrm{Ort}=3,98)$ sahiptir.

Dijital göçebeler geleneksel turistlerden farklı olarak daha uzun süreli konakladıkları ve yerel ile daha fazla iletişim içinde oldukları için destinasyon seçerken, şehirde yaya olarak ulaşım olanakları, trafiğin güvenliği, barış, mutluluk, yaşam kalitesi düzeyi ve konuşma özgürlüğü gibi 
konular önem taşımaktadır. Üç kümenin bu boyutlarına ilişkin ortalamalarına bakıldığında; yaya olarak ulaşım kolaylıklarının en yüksek ortalama $(\mathrm{Ort}=5,00)$ ile yüksek toleranslı-lüks destinasyonlar kümesinde olduğu, en düşük ortalamanın ise yine düşük sayılamayacak düzeyde 4,54 ile düşük tolerasnlı-ekonomik destinasyonlar kümesinde olduğu görülmektedir. Yaşam kalitesi düzeyi ortalamaları incelendiğinde; 4,03 ortalama ile yüksek toleranslı-lüks destinasyonlar en yüksek ortalamaya sahip iken düşük toleransll-ekonomik destinasyonlar 3,68 ortalama ile diğer kümelerin gerisindedir. Benzer şekilde kümelerin mutluluk ortalamalarında da en yüksek ortalama 4,32 ile yüksek toleransl1-lüks destinasyonlara ait iken en düşük mutluluk ortalaması 3,31 ile düşük toleransl1-ekonomik destinasyonlar kümesine aittir.

Dijital göçebelerin destinasyon seçerken göz önünde bulundurdukları önemli kriterlerden biri gece hayatı ve eğlence olanaklarıdır. Bu üç kümenin ortalamalarına bakıldığında yüksek toleransl1-lüks destinasyonların eğlence ortalamasının 4,25 ve gece hayatı ortalamasının 4,78 gibi yüksek bir ortalamaya sahip olduğu görülmektedir. Düşük toleransl1-ekonomik destinasyonlarda ise eğlence ortalaması 3,90 gece hayatı ortalaması ise $4,14^{\prime}$ tür. Son olarak yüksek toleranslı-ekonomik destinasyonların ortalamalarına bakıldığında eğlence 4,43 gece hayatı ise 3,64 ortalamaya sahiptir. Buna göre, eğlence boyutunda en yüksek ortalama yüksek toleranslı-ekonomik destinasyonlara ait iken gece hayatı boyutunda en yüksek ortalama yüksek toleransl1-lüks destinasyonlara aittir.

Dijital göçebeler için gidilecek şehirdeki iklim ve hava koşulları da önemlidir. Nomad List' de kriter olarak yer alan sıcaklık, nem, hava kalitesi, iklimlendirme sistemleri, dijital göçebelerin destinasyon seçiminde bu amaçla dikkate aldıkları kriterler olarak söylenebilir. Sıcaklık boyutunda en iyi ortalamaya düşük toleranslı-ekonomik destinasyonlar kümesi $(3,50)$ sahip iken, yıllık hava kalitesi ortalamasında yüksek toleranslı- lüks destinasyonlar kümesi 3,85 ortalama ile diğer iki kümeyi geride bırakmıştır. Nem kriteri ortalamalarına bakıldığında küme ortalamaları arasında farklılık çok düşüktür.

\section{SONUÇ ve ÖNERILER}

Bu çalışmada dijital göçebelerin önemli bağlantı ağlarından biri olan Nomad List verilerini kullanarak, 2020 pandemi sürecinde en çok tercih edilen 20 dijital göçebe destinasyonunun, yine aynı kaynakta yer alan ve dijital göçebelerin destinasyon seçerken dikkate aldıkları kriter skorlarını kullanarak nasıl kümelendiklerini belirlemek ve küme ortalamaları incelenmiştir. Dijital göçebe turizmi ile ilgili yapılan çok sınırlı sayıda araştırma olması araştırma sonucunda elde edilen bulguları benzer alanda yapılan çalışma sonuçları ile karşılaştıramama kısıtı doğurmuştur. Uluslararası alan yazında yeni olan dijital göçebe kavramının turizm alan yazınında bir turizm potansiyeli olarak yer alması ise son bir iki yılda ortaya çıkmıştır. Dijital göçebelerin turizm potansiyeli Ulusal alan yazında ise hiç incelenmemiştir. Araştırma konusu ile ilgili sınırlı sayıda çalışma olması kavramsal çerçevenin oluşturulmasında zorluklar yaratsa da araştırma ulusal alan yazında "dijital göçebe turizmi", "dijital göçebe destinasyonu" ve "dijital göçebe turisti" kavramlarını ilk ele alan araştırma olması açısından önemlidir.

İş ve toplumun mevcut dönüşümü, küreselleşme, girişimciliğin büyümesi, bağımsız çalışma, tele çalışma ve hareketlilik, dijital göçebeler, kendi kendine üretim, birlikte değer yaratma ve sosyal inovasyon gibi birçok nedenle biçim değiştirmektedir (Mitev vd., 2018). Bu değişim içerisinde dijital göçebe vizesi, e-vatandaşlık gibi kavramlar gündeme gelmekte ve hayat daha mobil bir yapıya dönüşmektedir. Bu dönüşüm içerisinde boş zaman ve iş kavramları arasındaki çizgi giderek bulanıklaşmakta ve turizm algısı da değişmektedir. Dijital göçebeler hem iş hem tatili aynı anda gerçekleştirebilen bu ayrımın bulanıklaştığı grupta yer almaktadır. 
Bu çalışma sonucunda elde edilen kümelerin dağılımına bakıldığında; Yüksek Toleranslı-Lüks Dijital Göçebe Destinasyonları, Düşük Toleranslı-Ekonomik Dijital Göçebe Destinasyonları ve Yüksek Toleranslı-Ekonomik Dijital Göçebe Destinasyonlar şeklinde ortaya çıkmasının üzerinde durulması gerekir. Destinasyonun sunduğu tüm hizmet ve imkanlar öncelikle o destinasyonun sahip olduğu ekonomik değişkenlere bağlıdır. Ekonomik faktörler destinasyonun, altyapı, üst yapı, yaşam kalitesi, yaşam maliyeti, gelir düzeyi gibi birçok faktörü üzerinde ektilidir. Diğer taraftan farklı bir destinasyona geleneksel turiste göre daha uzun bir süre için konaklamaya giden bir dijital göçebe için gittiği destinasyonun yabancılara bakış açısı, özgürlük, kadınlara hoşgörü gibi farklılıkları dikkate alan bir yer olması da önemlidir. Araştırmada kümeleme analizinde de bu iki kritere göre isimlendirme yapılmıştır. Gelir seviyesi yüksek bir destinasyonda yaşam maliyetinin, teknolojik altyapının, sağlık hizmetlerinin, eğitim seviyesinin, yaşam kalitesinin ve yabancı dil bilme oranlarının da yüksek olması nedenli ile tüm bunları kapsayan ekonomik kriter dikkate alınmıştır. Yüksek toleranslı-lüks dijital göçebe destinasyonu olan Londra, Berlin, New York, Paris Singapur, Amsterdam, San Francisco, Los Angeles kümesine bakıldığında, yaşam maliyetinin yüksek olduğu buna bağlı olarak da yukarıda sayılan tüm boyutlarda diğer kümelerden önde olduğu görülmektedir. Gelir seviyesi olarak yüksek gelir seviyesindeki dijital göçebelerin daha çok tercih ettiği bu destinasyonlarda olanaklar zengin olmakla birlikte yaşam maliyeti yüksektir. Düşük toleransl1-ekonomik dijital göçebe destinasyonları kümesinde yer alan Bangkok, Chiang Mai, Kuala Lumpur, İstanbul ve Ho Chi Minh City'ye bakıldığında bu destinasyonların yaşam maliyetinin uygunluğu ile dijital göçebelerin dikkatini çektiğini söylemek mümkündür. Gelir seviyesinin düşük olduğu, buna bağlı olarak diğer imkân ve olanakların daha sınırlı olduğu bu küme daha çok yüksek gelir seviyesine sahip olmayan dijital göçebeler için cazibe sunmaktadır. Bu kümenin yüksek toleransl1-ekonomik dijital göçebe destinasyonları kümesine göre ortalamalara bakıldığında tolerans konusunda daha düşük ortalamalara sahip olması dikkat çekmektedir. Daha özgür ve toleransın yüksek olduğu aynı zamanda da ekonomik olma özelliği ile ortalama olarak öne çıkan Canggu- Bali, Mexico City, Playe Del Carmen, Barcelona, Buenos Aires, Budapeşte ve Lisbon dijital göçebelerin dikkati çekmektedir. Dijital göçebeler için en popüler destinasyonlar arasında yer alan Bali ve Lisbon'da bu kümededir.

Kriterler içerisinde yer alan diğer sıcaklık, nem, hava kalitesi gibi iklim ile ilgili boyutlarda küme ortalamaları birbirine çok yakındır.

$\mathrm{Bu}$ çalışma Nomad List verileri kullanılarak, sadece platformda yer alan veriler kriterler bazındaki değerlendirmeler ile sınırlandırılmıştır. Bundan sonra yapılacak çalışmalarda dijital göçebelerin destinasyon seçim kriterlerinin birincil veri kullanılarak keşfedici bir yöntem ile araştırılması konuya önemli katkı sağlayacaktır. Bunun yanı sıra dijital göçebelerin profillerinin araştırılması, onları dijital göçebe olmaya iten ve çeken faktörlerin incelenmesi, dijital göçebelerin konaklama tercihlerinin incelenmesi, turizm işletmelerine ve yerel hakla sosyo-ekonomik pozitif ve negatif etkilerinin araştırılması, turizmde son yıllarda ele alınmaya başlayan dijital göçebe turizmi konusunda alan yazına sağlayacağı katkı açısından araştırılması önerilen başlıklardır.

\section{KAYNAKÇA}

Allahverdi, M. ve Alagöz, A. (2019). İllerin Vergi Gelirleri Açısından Sınıflandırılmasında Kümeleme Analizi Kullanımı. Maliye Dergisi. 176, 441-473.

Bouncken, B. and Reuschl, A. (2018). Coworking-Spaces: How A Phenomenon of The Sharing Economy Builds A Novel Trend for The Workplace and For Entrepreneurship. Rev Manag Sci. 12(1): 317-334. https://doi.org/10.1007/s11846-016-0215-y 
Chevtaeva, E. (2021). Information and Communication Technologies in Tourism 2021. Editors Wolfgang Wörndl. "Coworking and Coliving: The Attraction for Digital Nomad Tourists". Springer. 202-209.

Cook, D. (2020). The Freedom Trap: Digital Nomads and The Use of Disciplining Practices to Manage Work/Leisure Boundaries. Information Technology \& Tourism. 22(1): 355-390. https://doi.org/10.1007/s40558-020-00172-4.

Çolak, B., Durdağ, Z. ve Edoğmuş, P. (2016). K-Means Algoritması ile Otomatik Kümeleme. ElCezerî Fen ve Mühendislik Dergisi. 3(2): 315-323.

Gretzel, U and Hardy, A. (2019). \#VanLife: Materiality, Makeovers and Mobility amongst Digital Nomads, E-review of Tourism Research, 16(2): 1-9.

Hall, G., Sigala, M., Rentschler, R. and Boyle, S. (2018). Motivations, Mobility and Work Practices; The Conceptual Realities of Digital Nomads. Information and Communication Technologies in Tourism 2019: 437-449.

Heitmann, S., Robinson, P. and Povey, G. (2011). Slow food, slow cities and slow tourism. In P. Robinson, S. Heitmann, and P. Dieke (Eds.), Research Themes for Tourism (pp. 114-127). Wallingford: CAB International.

Hermann, I. and Paris C. M. (2020). Digital Nomadism: the nexus of remote working and travel mobility. Information Technology \& Tourism. 22: 329-334.

Kontogeorgopoulos, N. (2004) Conventional Tourism and Ecotourism in Phuket, Thailand: Conflicting Paradigms or Symbiotic Partners?, Journal of Ecotourism, 3(2): 87-108.

Makimoto, T. and Manners, D. (1997). Digital nomad. Chichester: John Wiley \& Sons.

Mulyana, C., Sudana, P. and Wikanatha Sagita, P. (2020). Persepsı Dan Motıvası Dıgıtal Nomad Berwisata Dı Desa Tibubeneng, Canggu, Kuta Utara. Jurnal IPTA (Industri Perjalanan Wisata). 8(2): 183-190.

Mouratidis G. (2018). Digital Nomadism: Travel, Remote Work and Alternative Lifestyle. Sweden: Lund University.

Nicholas, F. and Julian, M. (2021). Integrating Digital Nomads in Corporate Structures: Managerial Contemplations. Proceedings of the 54th Hawaii International Conference on System Sciences.

Mitev, N., de Vaujany, F.-X., Laniray, P., Bohas, A. and Fabbri, J. (2018). Co-working spaces, collaborative practices and entrepreneurship. Progress in IS, 15-43.

Orel, M. (2019). Coworking environments and digital nomadism: balancing work and leisure whilst on the move, World Leisure Journal, 61(3): 215-227.

Pecsek, B. (2018). Working on Holiday: The Theory and Practice of Workcation. Balkans JETSS, 1: $1-13$.

Prabawa, W. and Pertiwi, P. (2020). The Digital Nomad Tourist Motivation in Bali: Exploratory Research Based on Push and Pull Theory. Athens Journal of Tourism. 7(3): 161-174.

Putra, G. and Agirachman, A. (2016). Urban Coworking Space: Creative Tourism in Digital Nomads Perspective. Conference: Arte-Polis 6 International Conference At: Bandung, 1: 169-178.

Reichenberger, I. (2017). Digital nomads - A Quest for Holistic Freedom in Work and Leisure, Annals of Leisure Research, 21 (3): 1-17. 
Richards, G. (2015) The New Global Nomads: Youth Travel in A Globalizing World, Tourism Recreation Research, 40(3): 340-352.

Richter, A., Heinrich, P., Stocker, A. and Schwabe, G. (2018). Digital Work Design. Business $\mathcal{E}$ Information Systems Engineering. 60(3): 259-264.

UNWTO, (2021). International Tourist Numbers Down 65\% In First Half of 2020, Unwto Reports.

Valenduc, G. and Vendramin, P. (2016). Work in the digital economy:sorting the old from the new. Working papers-European Trade-Union Institute (ETUI). http://hdl.handle.net/2078.1/173373

Von Zumbusch, J. S. H. and Lalicic, L. (2020). The role of co-living spaces in digital nomads' wellbeing. Information Technology \& Tourism. 22: 439-453. https://doi.org/10.1007/s40558-020-00182-2

Wiranatha, A., Antara, M., Wiranatha, A., Piartrini, P., Pujaastawa I. and Suryawardani, G. A. (2020). Digital Nomads Tourism in Bali. Journal of Development Economics and Finance, 1(1): 1-16.

WYSE Travel Confederation (2018). New Horizons IV: A global study of the youth and student traveller. Project managers: Prof. Greg Richards and Wendy Morrill Published by: WYSE Travel Confederation.

www.nomadlist, Nomad List - Best Places for a Digital Nomad to Live [Erişim Tarihi: 15.01.2021]. 